\title{
Cecum Lymphoma
}

National Cancer Institute

\section{Source}

National Cancer Institute. Cecum Lymphoma. NCI Thesaurus. Code C5515.

An extranodal lymphoma that arises from the cecum. The majority are B-cell nonHodgkin lymphomas. 